\title{
Computer Science Students' Attitudes Towards the Use of Structured and Unstructured Discussion Forums in Fully Online Courses
}

\author{
Moanes H. Tibi \\ Computer Science Department, Beitberl College, Israel
}

\begin{abstract}
This study aims to investigate and analyze the attitudes and opinions of computer science students at two academic colleges of education with regards to the use of structured and unstructured discussion forums in computer science courses conducted entirely online. Fiftytwo students participated in two online courses. The students in each course were divided into two groups: the experimental group, which participated in a structured discussion forum, and the control group, which participated in an unstructured discussion forum. The questionnaire used for data collection consisted of closed and open-ended questions. The results revealed that the attitudes towards the use of discussion forums of students who participated in the structured discussion forum were positive compared to the attitudes of students who participated in the unstructured discussion forum. Based on the results of the study, the researcher suggests some appropriate recommendations.
\end{abstract}

Keywords: online learning; structured discussion forum; attitudes of computer science students

Tibi, M.H. (2018). Computer science students' attitudes towards the use of structured and unstructured discussion forums in online courses. Online Learning, 22(1), 93-106. doi:10.24059/olj.v22i1.995

\section{Computer Science Students' Attitudes Towards the Use of Structured and Unstructured Discussion Forums in Fully Online Courses}

The continued development and growth of internet-based technology has resulted in the development of many approaches to teaching and learning, manifested in various forms of online learning. In a traditional face-to-face class, students have several opportunities to interact with their instructor and to collaborate with their fellow students. Creating similar opportunities for meaningful discussion and collaboration in an online course is one of the biggest challenges of online instruction (Kelly, 2010).

Several modern computer-mediated communication (CMC) technologies can be utilized in online courses for the purpose of increasing collaborative interactions among the participants. Concurrently, the use of an asynchronous discussion forum (DF) is increasing in asynchronous 
online learning (Fear \& Brown, 2014; Zhou, 2015). Asynchronous DFs play a substantial role in humanizing online courses by replicating the classroom experience of information exchange and community building, not just between students and their instructor but also among the students themselves (Saadé \& Huang, 2009). In addition, these forums can be used to support, encourage, and facilitate learning. DFs can be unstructured or structured. An unstructured DF is primarily used to ask questions and obtain answers and feedback from participants rather than to post planned discussion topics (Yang, Newby \& Bill, 2008; Gao, 2014). In contrast, a structured DF provides well-designed and planned discussion activities with specific topics and goals (Yang et al., 2008), and has clear interaction and collaboration rules (Biesenbach-Lucas, 2004; Brooks \& Jeong, 2006).

Since interaction and collaboration through DFs can be an important factor in student success, positive student attitudes towards the use of DFs are linked to positive attitudes about asynchronous online learning in general. The aim of this study is to investigate and measure students' attitudes toward the use of structured and unstructured DFs in fully online computer science courses. Specifically, the present study sought answers to the following questions: What are students' attitudes towards the use of structured and unstructured DFs? What are students' suggestions regarding the use and the structure of DFs in computer science online courses?

\section{Review of Related Literature}

Constructivism emphasizes social interaction as a basis for knowledge construction. Paloff \& Pratt (2007) emphasize that "key to the learning process are the interactions among students themselves, the interactions between faculty and students, and the collaboration in learning that results from these interactions" (p. 4). Many educators agree that interaction and discussion between students and their instructor and among students themselves are critical to promote and enhance online learning (Anderson, 2003; Dalelio, 2013; Muirhead \& Juwah, 2004; Palloff \& Pratt, 2007; Saadé \& Huang, 2009; Swan, 2002; Wegmann \& McCauley, 2014). How online courses are organized, therefore, is an essential component of improved interaction and collaboration among students.

Asynchronous DFs provide opportunities for collaborative learning and teaching transactions (Kelly, 2010; Saadé \& Huang, 2009) in asynchronous online courses. Participation in a DF demands that students become actively engaged with the course content and learning activities. Through interaction with their peers, students learn to negotiate the meaning of the content (Fear \& Brown, 2014; Serena, 2009). DFs also allow the creation of collaborative knowledge, since learners work together, exchange information, share resources and ideas, and comment on each other's work (Gao, 2014; Preece, 2000; Serena, 2009). Markel (2001) maintained that students construct knowledge through the shared experiences that each participant brings to collaborative discussions. However, studies show that simply asking students to participate in DFs is not likely to generate an effective collaborative learning environment (Ali \& Salter, 2004; Andresen, 2009; Gilbert \& Dabbagh, 2005).

\section{Unstructured and Structured Discussion Forums}

A DF can be unstructured or structured. An unstructured DF does not include planned discussion, nor does it provide rules for interaction and collaboration among participants. It is primarily used to ask questions and obtain answers and feedback from participants; therefore, it 
requires students to create their own discussion (Yang et al., 2008; Salter \& Conneely, 2015). Unstructured DFs are sometimes used by students for personal peer communication. In contrast, a structured DF provides well-designed, organized, and planned discussion, usually set by the instructor with specific topics and goals (Yang et al., 2008). In addition, a structured DF has clear interaction, collaboration, and etiquette rules (Biesenbach-Lucas, 2004; Brooks \& Jeong, 2006). Researchers have argued that a major challenge facing instructors of online courses is to structure asynchronous discussions that will engage students in meaningful discourse (Gilbert \& Dabbagh, 2005; Wallace, 2003; Wozniak \& Silveira, 2004).

Previous research has shown that structured DFs are more effective than unstructured DFs for the acquisition of different kinds of knowledge, in particular know-how (refers to the ability to do something) and know-why (refers to knowledge about the nature of causality in the human mind and in society) (Tibi, 2013). It has also been shown that structured DFs are more effective for the improvement of critical thinking skills (Aviv, Erlich, Ravid \& Geva, 2003; Gilbert \& Dabbagh, 2005; Yang et al., 2008) and collaborative skills (Tibi, 2015) than are unstructured DFs. Salter and Conneely (2015) found that structured DFs were generally perceived by students to be more engaging than unstructured DFs.

\section{Purpose of the Study}

The purpose of this study is to investigate whether the introduction of structured DFs into computer science fully online courses is effective in terms of improving students' perceptions of the learning environment and their attitudes towards the use of DFs.

\section{Research Objectives}

\section{Methods}

The purpose of the present study is twofold:

- To investigate and measure students' attitudes towards the use of structured and unstructured DFs in fully online computer science courses;

- To explore students' suggestions that might help in redesigning the DF for a better learning experience for the learners.

On the basis of these research objectives, the following study hypotheses will be examined:

Hypothesis 1: instructor feedback will significantly affect discussions in the two types of DFs (structured and unstructured).

Hypothesis 2: students of the structured DFs will share significantly more knowledge among themselves than students of the unstructured DFs.

Hypothesis 3: student perception of the overall structure and organization of the two types of DFs (structured and unstructured) will differ greatly.

\section{Research Participants}

The participants in the survey are Arab students in computer science programs at two academic colleges of education. Both colleges are located in the center of Israel and are heterogeneous in the following respects: (1) students come from different villages and towns located in north, center, and south of Israel; (2) students come from families with variable socioeconomic and educational status. All participants began post-secondary education 
immediately upon completion of high school. In education colleges, students study computer science in order to teach it in elementary and junior high schools. Thus, in addition to computer science courses, students in education colleges also study courses in pedagogy and education.

In this study, two different computer science online courses with a total participant count of 52 students were examined. Both courses, entitled "Internet Programming using JavaScript," had the same content and instructor. The number of enrollees in the first course was 28 students, and in the second course, 24 students. Students in each course were randomly divided into two equal groups. One group participated in an unstructured DF and was considered the control group $(\mathrm{N}=26)$. The other group participated in a structured DF (i.e. the treatment) and was considered the experimental group ( $\mathrm{N}=26)$. Instruction was offered in Arabic since the instructor and all students are Israeli-Arabs.

\section{Research Instrument}

The instrument used in the survey was a questionnaire distributed to all participants during a face-to-face meeting at the end of the course. The questionnaire consisted of closeended questions that were answered on a five-point Likert scale, ranked from 1-5 with 1 indicating "strong disagreement" and 5 indicating "strong agreement," and of open-ended questions asking students to provide their opinions and suggestions about the use of DFs in the online course.

Design of the Structured Discussion Forum. The structured DFs used in this study consisted of the following three elements: (1) preparatory instructions about individual participation, (2) instructions about group collaboration, and (3) the instructor's role in organizing the discussion. The following is a summary of steps taken to design the structured DF.

- In the first step, the instructor explained how students would be evaluated in the course, the purpose and nature of the discussions in the DFs, and the rules for participation in the DFs in order to keep the discussions organized. The assessment rubric given to students consisted of the following elements: (1) grade weight of participation in the discussion forums, (2) grade weight of the examination, (3) grade weight of individual assignments and (4) grade weight of the final group project.

- The instructor then constructed small groups of three or four students with mixed knowledge levels. Each group received a group name.

- The instructor established a DF for each small group.

- Students were then informed about the objective of establishing small group DFs and encouraged to use these forums to enhance their interaction and collaboration around the learning materials and group learning activities.

- Students were requested to participate actively in two discussion groups. The first was the central DF where students from all small groups participated; the second was the small group DF. The role of the instructor in each group discussion was explained.

- The instructor was actively involved in the central DF to create a learning environment that motivated students to construct knowledge through meaningful interaction with each other as well as with their instructor. The instructor regularly posted questions on different levels of knowledge and provided feedback to students' posts. 
- The instructor posted lists of questions and problems to be solved and related each question to a different student. Students then answered the questions directed to them and, as requested, offered comments on other students' answers within a given period of time.

- In the middle of the semester, the instructor organized a group activity that asked each group of students to study a different subject and to prepare a learning unit about it. The subject they received included three questions, each related to a different kind of knowledge.

- Each group was then required to study and discuss a learning unit of a different group, as specified by the instructor. They were asked to post answers to the questions and to comment on the learning unit within a specified deadline. Then, each group was requested to review the feedback they received and to comment on it.

- Aside from continuous feedback and support throughout the course, the instructor also sent monthly personal, positive feedback to students about their level of participation, which motivated students with low participation to be more active in the DFs.

- At the end of the semester, each small group of students was required to complete a final project which was clearly described by the instructor.

\section{Design of the Unstructured Discussion Forum}

Students of the control group participated in the unstructured DF. At the beginning of the online course, the instructor explained how students would be evaluated in the course. The instructor emphasized the importance of using the DF for information exchange and feedback among participants. The instructor also encouraged students to use the DF whenever they had questions regarding vague learning materials. The instructor responded to all questions directed to him. In addition, the instructor posted questions about the learned course materials to the DF without directing these questions to individual students. The role of the instructor in the unstructured DF was more "guide on the side," jumping in when necessary, rather than actively designing, organizing, and planning the discussions. Students of the unstructured DF were not requested to work in small groups or to lead any group activity. Students submitted their work/project individually. On the other hand, they had the opportunity to organize and manage the discussions as they liked and to collaborate with each other. Thirty percent of the final grade was given for active participation in the structured as well as in the unstructured DFs.

\section{Limitations of the Study}

Effective evaluation of student participation in discussion forums, whether in structured or unstructured forums, would require a more detailed assessment rubric. The use of a grading rubric that includes standards of performance is one factor that affects the quality of the discussion forum (Craig, 2015). In addition, giving students clear information about how participation in discussion forums will be assessed provides extrinsic motivation. The lack of a clear and detailed grading rubric to assess discussion forums in this study was one of its limitations and weaknesses. 


\section{Results}

The number of respondents who completed the survey was 52; half participated in the structured DFs and the other half participated in the unstructured DFs. In general, students had significantly more positive responses (quantitatively and qualitatively) about participation in the structured DFs compared to those who participated in the unstructured DFs. First, quantitative results will be shown and then qualitative responses to open-ended questions will be described.

Quantitative results suggest that students responded more positively to the structured DF $(\mathrm{M}=4.20, \mathrm{SD}=.55)$ than to the unstructured $\mathrm{DF}(\mathrm{M}=3.38, \mathrm{SD}=.81)$. The following paragraphs describe the results from both groups (structured and unstructured) according to the statements that were given to students in order to examine the three hypotheses of the study (See Table 1 for quantitative analyses of the statements).

\begin{tabular}{|c|c|c|c|c|c|}
\hline \multicolumn{2}{|c|}{ Statement } & \multicolumn{2}{|c|}{$\begin{array}{l}\text { Structured } \\
\text { DF }\end{array}$} & \multicolumn{2}{|c|}{$\begin{array}{l}\text { Unstructured } \\
\text { DF }\end{array}$} \\
\hline & & Mean & SD & Mean & SD \\
\hline Q1 & $\begin{array}{l}\text { My participation in the DF contributed to } \\
\text { the building of knowledge by other } \\
\text { classmates }\end{array}$ & 4.04 & .60 & 3.12 & .86 \\
\hline Q2 & $\begin{array}{l}\text { The instructor's role in organizing the } \\
\text { discussion within the DF was clear }\end{array}$ & 4.08 & .48 & 3.38 & .90 \\
\hline Q3 & $\begin{array}{l}\text { Getting feedback on the DF from the } \\
\text { instructor helped me understand the course } \\
\text { materials better }\end{array}$ & 4.19 & .49 & 3.85 & .83 \\
\hline Q4 & $\begin{array}{l}\text { I think that my willingness to share } \\
\text { knowledge with others has increased }\end{array}$ & 4.15 & .37 & 3.69 & .47 \\
\hline Q5 & I liked the way the DF was organized & 4.23 & .59 & 2.69 & .84 \\
\hline Q6 & $\begin{array}{l}\text { I think that the forum content was not well } \\
\text { organized }\end{array}$ & 1.46 & .51 & 1.96 & .72 \\
\hline Q7 & $\begin{array}{l}\text { I think the participants of the DF shared a } \\
\text { lot of knowledge with each other }\end{array}$ & 4.04 & .66 & 2.27 & .87 \\
\hline Q8 & $\begin{array}{l}\text { Getting feedback on the DF from the } \\
\text { instructor motivated me to participate more } \\
\text { in the DF }\end{array}$ & 4.38 & .64 & 3.38 & .85 \\
\hline
\end{tabular}

Table 1. Quantitative Study Questions

\section{Hypothesis 1: Instructor Feedback}

Instructor feedback and support in DFs is important for students because it promotes effective interaction and collaboration among group members. Students were asked whether the instructor's feedback motivated them to participate more in the DF (Q8). Students of the structured $\mathrm{DF}$ agreed with this statement $(\mathrm{M}=4.38, \mathrm{SD}=.64)$ more than students of the 
unstructured $\mathrm{DF}(\mathrm{M}=3.38, \mathrm{SD}=.85)$. Students of the structured $\mathrm{DF}$ also agreed with the statement that "the instructor's feedback helped them understand the course materials better" $(\mathrm{M}=4.23, \mathrm{SD}=.51)$ more than students using the unstructured $\mathrm{DF}(\mathrm{M}=3.81, \mathrm{SD}=.85)$. See Table 1 for this and all other quantitative analyses. The category of statements $(\mathrm{C} 1)$ for measuring hypothesis number 1 consisted of the three statements Q2, Q3, and Q8. The Cronbach's Alpha for this category was .746, which shows good reliability. Means and standard deviations for this and other categories are listed in Table 2.

\section{Hypothesis 2: Knowledge Sharing}

Hypothesis 2 suggested that students of the structured DF shared more knowledge among themselves than students of the unstructured DF. The category of statements for measuring this hypothesis consisted of the three statements Q1, Q4, and Q7. The Cronbach's Alpha for this category was .673, which is almost good reliability. The results show that students of the structured DF reported sharing significantly more knowledge among themselves $(\mathrm{M}=4.34, \mathrm{SD}=.46)$ than students using the unstructured $\mathrm{DF}(\mathrm{M}=3.28, \mathrm{SD}=.53)$.

\begin{tabular}{|l|l|r|r|r|r|}
\hline Category & Group & N & Mean & Std. Deviation & $\begin{array}{l}\text { T value } \\
(\mathrm{Df}=50)\end{array}$ \\
\hline C1 & structured & 26 & 4.07 & .41 & $8.45^{* * *}$ \\
& Unstructured & 26 & 3.02 & .48 & \\
C2 & structured & 26 & 4.34 & .46 & $7.63 * * *$ \\
& Unstructured & 26 & 3.28 & .53 & \\
C3 & structured & 26 & 4.23 & .41 & $4.54 * * *$ \\
& Unstructured & 26 & 3.52 & .67 & \\
\hline
\end{tabular}

$* * * \mathrm{p}<.001$

Table 2. Means, Standard Deviations, and T value of Each Category for Testing the Hypotheses in Both Groups

\section{Hypothesis 3: Student Perceptions of Overall Structure and Organization}

Hypothesis 3 suggested that there would be differences in how students find the overall structure and organization of the DF (statements Q5 and Q6). Students using the structured DF agreed with the statements $\mathrm{Q} 5$ and $\mathrm{Q} 6(\mathrm{M}=4.23, \mathrm{SD}=.41)$ more than students using the unstructured $\mathrm{DF}(\mathrm{M}=3.52, \mathrm{SD}=.67)$. The result of the Pearson correlation was found to be positive ( $\mathrm{r}=.27, \mathrm{P}=.058)$.

In the three categories $\mathrm{C} 1, \mathrm{C} 2$, and $\mathrm{C} 3$ that measured hypotheses $\mathrm{H} 1, \mathrm{H} 2$, and $\mathrm{H} 3$ respectively, the results showed that students of the structured DF had significantly more positive responses than students of the unstructured DF. Table 2 shows the result of the conducted t-test for independent sample.

\section{Qualitative Comments}

The questionnaire also included open-ended questions. Students were asked to describe what they liked or did not like concerning the organization and structure of the DF. They also had the opportunity to share their observations and suggestions. The following is a summary of comments by students concerning the points raised as answers to open-ended questions. 


\section{Organization and Management of the DF}

Students were asked to describe what they liked and did not like regarding the organization and management of the DF. Almost all of the qualitative comments given by students from both groups to this particular question were positive. This result is in agreement with the quantitative results obtained from the statement Q6. Table 3 shows the qualitative comments given by the students to this question.

\begin{tabular}{lll}
\hline Group & Liked & Did not like \\
\hline Structured & The organization was very good & $\begin{array}{l}\text { Sometimes discussion topics were not } \\
\text { closed }\end{array}$ \\
& $\begin{array}{l}\text { The management was very good } \\
\text { The comments of the instructor were } \\
\text { clear }\end{array}$ & $\begin{array}{l}\text { At first it was stressful because of the } \\
\text { tasks }\end{array}$ \\
& Precise timing & \\
\hline Unstructured & $\begin{array}{l}\text { The organization and management } \\
\text { were good } \\
\text { Things were clearly organized }\end{array}$ & $\begin{array}{l}\text { Little monitoring of instructor } \\
\text { Sometimes the responses were late }\end{array}$ \\
\hline
\end{tabular}

Table 3. Qualitative Responses to the Organization and Management of the DF

\section{Participation and Interaction in the DF}

Students were also asked to discuss what they liked or did not like concerning the participation and interaction in the DF (Table 4). Qualitative responses from both groups differed. Students of the structured DF found the level of participation and interaction significantly higher than that found by students of the unstructured DF. This difference can be supported by the quantitative results obtained from statement Q7. This lends support to the suggestion that students in the structured DF interacted and shared more together than did students of the unstructured DF.

\begin{tabular}{lll}
\hline Group & Liked & Did not like \\
\hline Structured & I liked the participation and interaction; & Not everyone participated in the same \\
& it encouraged the group members. & level. \\
& We cooperate for success. & Not everyone responded to my post. \\
& Good, but it took a lot of time. & Some students had little participation. \\
& $\begin{array}{l}\text { The communication of the instructor } \\
\text { with us was outstanding and helped us }\end{array}$ & The participation in the DF required a \\
in many situations. & lot of time. \\
\hline Unstructured & $\begin{array}{l}\text { Not high. After answering the } \\
\text { questions, the debate almost ends. }\end{array}$ & $\begin{array}{l}\text { Participation was not in a significant } \\
\text { level. }\end{array}$ \\
& $\begin{array}{l}\text { There was no high-level interaction, } \\
\text { but we benefited from it. }\end{array}$ & $\begin{array}{l}\text { The interaction between the students } \\
\text { was weak. }\end{array}$ \\
& & I did not like it. Everyone was working \\
& alone.
\end{tabular}

Table 4. Qualitative Responses about the Level of Participation and Interaction in the DF 


\section{Questions and Tasks Given in the DF}

Another questionnaire item dealt with the type of questions and tasks given by the instructor in the DF. Students were requested to comment on what they liked or did not like with regards to the questions and tasks given in the DF. The responses of students participating in the structured DF were clearly more positive than those offered by students of the unstructured DF. Table 5 summarizes the qualitative responses given by students of both groups to this question.

\begin{tabular}{lll}
\hline Group & Liked & Did not like \\
\hline Structured & $\begin{array}{l}\text { Questions were stimulating and gave birth } \\
\text { to a competition between group members. } \\
\text { Questions on different levels of knowledge } \\
\text { were meaningful and helped me to } \\
\text { understand the materials of the course. }\end{array}$ & $\begin{array}{l}\text { There were many questions and } \\
\text { tasks. } \\
\text { I liked the individual questions for each } \\
\text { time to answer all of them. }\end{array}$ \\
& $\begin{array}{l}\text { Tasks were gradual from easy to difficult. } \\
\text { Group tasks were challenging. }\end{array}$ & \\
& The questions were clear. & \\
\hline Unstructured & The course materials contributed to my & $\begin{array}{l}\text { Questions did not lead to a big } \\
\text { understanding of the learned subjects. }\end{array}$ \\
& & $\begin{array}{l}\text { You did not need to participate } \\
\text { on an ongoing basis, except in } \\
\text { solving tasks. }\end{array}$ \\
\hline
\end{tabular}

Table 5. Qualitative Responses about the Questions and Tasks Given by the Instructor in the DF

\section{Suggestions and Notes for Next Online Course}

In addition to the above-mentioned qualitative responses, students were also asked to give their notes and suggestions. The suggestions and notes provided by students are listed in Table 6.

\begin{tabular}{ll}
\hline Structured & I was very pleased to learn this course. \\
& It is better to integrate $\mathrm{f} 2 \mathrm{f}$ meetings in the course, since the materials of the \\
course require that. \\
I suggest more individual questions for each student. \\
\hline Unstructured & I think there is a need for more communication with the instructor in the DF. \\
& A good and useful experience, but I prefer to learn programming in $\mathrm{f} 2 \mathrm{f}$ \\
meetings. & \\
Members of the DF where not connected together.
\end{tabular}

Table 6. Suggestions and Notes Written by Students of the Structured and Unstructured DF 


\section{Discussion}

In the current study, two types of discussion forums were examined: the structured and the unstructured DF. Students' attitudes about, and opinions towards, the two kinds of DF varied widely. Students of the structured DF generally had stronger and more positive attitudes and reactions towards the use of DF than students of the unstructured DF. Students using the structured DF liked the organization and structure of the DF more than the students of the unstructured DF. Specifically, students of the structured DF felt more motivated by the instructor's feedback to participate in the forum than the students of the unstructured DF. This result is also supported by the findings obtained from the statement about the level of interaction between participants in the DF. One possible explanation of this finding is the instructor's role in the structured DF. At the beginning of the online course, students in the structured DF (experimental group) received preparatory instructions and clear directions for online discussions. This information included an assessment rubric, clear explanations about the purpose of the discussion forum, instructions about how to use it, and instructions about group collaboration. Clear and simple directions for online discussion and setting out expectations are important in making student-to-student interactivity more effective (Dalelio, 2013; Mokoena, 2013; Wozniak \& Silveira, 2004) and to motivate students to contribute to discussions (AlShalchi, 2009; Lall \& Lumb, 2010; Roper, 2007). In addition, regular and controlled instructor involvement in the discussion forum through feedback, support, and questioning helped to organize the discourse and create effective and oriented discussion. As a result, students were motivated to contribute to ongoing discussions and to construct meanings through interaction with each other, the content, and the instructor. This explanation is also supported by previous research on online discussions, which showed that instructor participation and support in the DF often encourages student interaction and participation (Bender, 2003; Dalelio, 2013; Kearsley, 2000; Mokoena, 2013) and makes the discussion more effective and successful (Al-Shalchi, 2009; Lall \& Lumb, 2010; Prasad, 2009).

Similarly, students using the structured DF agreed with the statement "the instructor's feedback helped me understand the course materials better" more than students using the unstructured DF. In addition, qualitative student responses supported this result. In this study, the instructor regularly posted a variety of questions and authentic problems on different types of knowledge (know-what, know-how, and know-why) in an attempt to make discussions more effective and to promote a deep understanding of the subjects being learned. Several studies have shown that students favored a variety of questions asked in the discussion forum (Andresen, 2009; Akin \& Neal, 2007; Gao, 2014; Roper, 2007). "The questions asked by the instructor should not be mundane or ask for recall of memorized facts, but instead should be challenging so that they attempt to deepen enquiry and improve the opportunities to actively acquire knowledge" (Bender, 2003; p. 178). During the course, one activity directed each question to a different student. Students were asked to answer their questions and to comment on other students' answers within a given period of time. This method of activating the discussion forum helped students to better understand the learned materials and to be more involved in discussing, analyzing and constructing knowledge.

Interestingly, students of the structured DF collaborated and shared more knowledge than students of the unstructured DF. Unlike students of the unstructured DF, students of the structured one participated in small group collaborative activities and carried out a final group project. They also received clear instructions about group collaboration and were directed and 
encouraged to work collaboratively. Working collaboratively on group activities or projects promoted mutual recognition of each member's importance and contribution to the group's success and thus challenged each other's ideas and facilitated each other's efforts in order to reach the group's goals. In such a situation, students within the collaborative small group were linked together, held accountable for the group's work, received help and assistance from each other, shared resources and materials, and provided each other with feedback in order to successfully perform the group activity. This explanation is also consistent with the results of other studies (Benaya \& Zur, 2007; Kalayci \& Humiston, 2015; McKinney \& Denton, 2006; Teague \& Roe, 2007) which showed that the integration of collaborative activities into online computer science courses benefits student learning as well as the development of skill sharing. Another explanation for the above finding may be that the students of the experimental group, unlike students of the control group, participated in two levels of discussions: the small group DF and the central DF. Establishing a DF for each small group of students and asking them to work together on the group activities helped to keep every member involved in the discussion (Felder \& Brent, 1994; Rau \& Heyl, 1990), enabled group members to create a sense of community of learners with shared goals, and allowed students to manage the discussion according to their needs. This way of organizing the online discussion increased group interaction and interdependence (Hara, Bonk \& Angeli, 2000).

\section{Conclusions and Implications}

Results indicated that students who participated in the structured DF had significantly more positive responses and attitudes, both quantitatively and qualitatively, than students of the unstructured DF. Gaining more positive attitudes towards the use of DFs in online courses is an important factor that affects students' attitudes towards asynchronous online learning. From the findings of this study emerged a number of suggestions for instructors regarding the structure and management of asynchronous DFs in educational settings. These suggestions may be applicable to other disciplines as well.

In the structured DF, students mainly worked together in small groups. Each small group delivered a final project at the end of the course. It would be of interest to plan a class collaborative project wherein each small group would be responsible for one part of the project which, when assembled, would complete the project. Adding this component to the structured DF might increase inter-group collaboration and contribute to student learning and understanding since students who are actively involved in projects can learn more and develop more positive attitudes than students who are not. Another possible direction could be to compare the effects of different kinds of structured DFs (structured, semi-structured, and unstructured) on students' learning and their attitudes and perceptions towards the use of different kinds of DF. 
Computer Science Students' Attitudes Towards the Use of Structured and Unstructured Discussion Forums in Fully Online Courses

\section{References}

Akin, L., \& Neal, D. (2007). CREST+ Model: Writing effective online discussion questions. Journal of Online Learning and Teaching, 3(2). Retrieved from http://jolt.merlot.org/vol3no2/akin.htm

Ali, S., \& Salter, G. (2004). The use of templates to manage on-line discussion forums. Electronic Journal on e-Learning 2(1), 11-18. Retrieved from http://digilib.unsri.ac.id/download/issue1-art6-ali-salter.pdf

Al-Shalchi, O. (2009). The effectiveness and development of online discussion. (Electronic version). MERLOT Journal of Online Learning and Teaching, 5(1), 104-108.

Andresen, M. A. (2009). Asynchronous discussion forums: success factors, outcomes, assessments, and limitations. Educational Technology \& Society, 12 (1), 249-257.

Anderson, T. (2003). Getting the mix right again: An updated and theoretical rationale for interaction. The International Review of Research in Open and Distance Learning, 4(2). Retrieved March 02, 2009 from http://www.irrodl.org/index.php/irrodl/article/view/149/230

Aviv, R., Erlich, Z., Ravid, G., \& Geva, A. (2003). Network analysis of knowledge construction in asynchronous learning networks. Journal of Asynchronous Learning Networks, 7(3), 1-23.

Benaya, T., \& Zur, E. (2007). Collaborative programming projects in an advanced CS course. Journal of Computing Sciences in Colleges, 22(6), 126-135.

Bender, T. (2003). Discussion-based online teaching to enhance student learning: Theory, practice and assessment. Sterling, Virginia: Stylus Publishing.

Biesenbach-Lucas, S. (2004). Asynchronous web discussions in teacher training courses: Promoting collaborative learning — or not? AACE Journal, 12(2), 155-170.

Brooks, C. D., \& Jeong, A. (2006). Effects of pre-structuring discussion threads on group interaction and group performance in computer supported collaborative argumentation. Distance Education, 27(3), 371-390.

Craig, G. P. (2015). Evaluating Discussion Forums for Undergraduate and Graduate Students. Faculty Focus, Magna Publications. Retrieved Mai 07, 2017 from https://www.facultyfocus.com/articles/online-education/evaluating-discussion-forumsundergraduate-graduate-students/

Dalelio, C. (2013). Student Participation in Online Discussion Boards in a Higher Education Setting. International Journal on E-Learning, 12(3), 249-271.

Fear, W. J., \& Brown, A. E. (2014). Good quality discussion is necessary but not sufficient in asynchronous tuition: A brief narrative review of the literature. Online Learning, 18(2).

Felder, R. M., Brent, R. (1994). Cooperative learning in technical courses: Procedures, pitfalls, and payoffs. National Science Foundation Division of Undergraduate Education. Retrieved March 10, 2009 from http://www.eric.ed.gov/PDFS/ED377038.pdf 
Gao, F. (2014). Exploring the Use of Discussion Strategies and Labels in Asynchronous Online Discussion. Online Learning, 18(3). Retrieved from $\underline{\text { ttp }: / / o l j . o n l i n e l e a r n i n g c o n s o r t i u m . o r g / i n d e x . p h p / o l j / a r t i c l e / v i e w / 460 ~}$

Gilbert, P. K., \& Dabbagh, N. (2005). How to structure online discussions for meaningful discourse: a case study. (Electronic version). British Journal of Educational Technology, 36(1), 5-18.

Hara, N, Bonk, C. \& Angeli C. (2000). Content analysis of online discussion in an applied educational psychology course. (Electronic version). Instructional Science, 28(2) 115152.

Kalayci, S., \& Humiston, K. R. (2015). Students' Attitudes Towards Collaborative Tools in a Virtual Learning Environment. Educational Process: International Journal (EDUPIJ), 4(1-2), 71-86.

Kearsley, G. (2000). Online Education: Learning and teaching in cyberspace. Belmont, CA: Wadsworth Publishing.

Kelly, R. (2010). Synchronous and asynchronous learning tools: 15 strategies for engaging online students using real-time chat, threaded discussions and blogs. Faculty Focus.

Lall, V., \& Lumb, R. (2010). Successful design, development and delivery of online courses: Lessons from operations management and global leadership. Indian Journal of Economics \& Business, 9(2), 377-384.

Markel, S. L. (2001). Technology and education online discussion forums: It's in the response. Online Journal of Distance Learning Administration, 4(2). Retrieved Mai 15, 2008 from http://www.westga.edu/ distance/ojdla/summer42/markel42.hml

Mazzolini, M., \& Maddison, S. (2007). When to jump in: The role of the instructor in online discussion forums, Computers \& Education, 49(2), pp. 193-213.

McKinney D., \& Denton, L.F. (2006). Developing collaborative skills early in the CS curriculum in a laboratory environment. Technical Symposium on Computer Science Education. Reviewed from http://www.cis.usouthal.edu/ mckinney/fp224mckinney.pdf

Mokoena, S. (2013). Engagement with and participation in online discussion forums. TOJET: The Turkish Online Journal of Educational Technology, 12(2).

Muirhead, B., \& Juwah, C. (2004). Interactivity in computer-mediated college and university education: A recent review of the literature. (Electronic version). Educational Technology \& Society, 7(1), 12-20.

Palloff, R. \& Pratt, K. (2007). Building online learning communities. San Francisco: JosseyBass.

Prasad, D. (2009). Empirical Study of Teaching Presence and Critical Thinking in Asynchronous Discussion Forums. International Journal of Instructional Technology \& Distance Education, 6(11). Retrieved from http://www.itdl.org/Journal/Nov 09/article01.htm 
Preece, J. (2000). Online communities: Supporting sociability, designing usability. Chichester, UK: Wiley.

Rau, W. \& Heyl, B. S. (1990). Humanizing the college classroom: Collaborative learning and social organization among students. Teaching Sociology, 18(2), 141-155.

Roper, A. R. (2007). How students develop online learning skills. Educause Quarterly, 30(1), 62-65. Retrieved from http://net.educause.edu/ir/library/pdf/EQM07110.pdf

Saade, G. R., \& Huang, Q. (2009). Meaningful learning in discussion forums: Towards discourse analysis. Issues in Informing Science and Information Technology, 6(1), 8799.

Salter, N. P., \& Conneely, M. R. (2015). Structured and unstructured discussion forums as tools for student engagement. Computers in Human Behavior, 46, 18-25.

Serena, W. Y. (2009). The impact of online discussion on face-to-face discussion and academic achievement. American Secondary Education, 37(2), 4.

Swan, K. (2002). Building learning communities in online courses: the importance of interaction (Electronic version). Education, Communication \& Information, 2(1), 2349.

Teague, D., \& Roe, P. (2007). Learning to program: Going pair-shaped. ITALICS, 6(4), 4-22.

Tibi, M. H. (2013). The Impact of Structured Discussion Forums on Knowledge Acquisition of Different Kinds by Computer Science Students, EDULEARN13, 1st-3rd July 2013, Barcelona, Spain, 3676-3690, ISBN: 978-84-616-3822-2.

Tibi, M. H. (2015). Improving Collaborative Skills by Computer Science Students through Structured Discussion Forums. Journal of Technologies in Education, 10 (3-4), 27-41.

Wallace, R. M. (2003). Online learning in higher education: A review of research on interactions among teachers and students. Education, Communication, and Information, 3(2), 241-280.

Wegmann, S. J., \& McCauley, J. K. (2014). Investigating Asynchronous Online Communication: A Connected Stance Revealed. Journal of Asynchronous Learning Networks, 18(1), n1.

Wozniak, H., \& Silveira, S. (2004). Online discussions: Promoting effective student to student interaction. In R. Atkinson, C. McBeath, D. Jonas-Dwyer \& R. Phillips (Eds.), Beyond the Comfort Zone: Proceedings of the 21st ASCILITE Conference, (pp. 956-960) Retrieved from http://www.ascilite.org.au/conferences/perth04/procs/pdf/wozniak.pdf.

Yang, Y.T., Newby, T., \& Bill, R. (2008). Facilitating interactions through structured webbased bulletin boards: A quasi-experimental study on promoting learners' critical thinking skills. Computers \& Education 50(4), 1572-1585. Retrieved from http://conf.ncku.edu.tw/research/articles/e/20080314/6.pdf

Zhou, H. (2015). A Systematic Review of Empirical Studies on Participants' Interactions in Internet-Mediated Discussion Boards as a Course Component in Formal Higher Education Settings. Online Learning, 19(3). Retrieved from http://olj.onlinelearningconsortium.org/index.php/olj/article/view/675 